\title{
Outing drug company corruption comes at a cost
}

\author{
MARYANNE DEMASI
}

\section{Jim Gottstein, The Zyprexa Papers, Samizdat Health; 2020, 232 pages, \$6.10 (Kindle), \$ 17.50 (Paperback) ISBN: 978-0-578 62726-7.}

Harvard-trained lawyer Jim Gottstein is the author of the new book, The Zyprexa Papers. It is a compelling, first-hand account of how a humble attorney from Alaska manages to expose the rot inside one of the biggest pharmaceutical companies in the world.

The story could easily be adapted to a screenplay, as the courtroom drama unfolds, complete with transcripts from the trial. The story centres around the release of internal documents belonging to Eli Lilly, the pharmaceutical giant that manufactures the antipsychotic drug, Zyprexa. The internal documents reveal that Eli Lilly deliberately concealed knowledge that Zyprexa causes significant weight gain, diabetes, and other metabolic problems in a large percentage of patients ( $p$ 91). Not only had the drug company withheld the information from doctors, but it had actively denied there was a problem.

Gottstein embarks on a journey to expose the documents, complicated by the fact that they are protected by a secrecy order. Unfortunately, the process by which Gottstein ultimately obtains the documents is not bulletproof, and it leaves him vulnerable to attack. The internal documents wind up on a public server and become the subject of an article in The New York Times (1), triggering a cascade of events that puts Gottstein squarely in the cross hairs of Eli Lilly.

While Gottstein maintains that he obtained the documents legally, the United States District Court for the Eastern District of New York ruled that he had violated the terms of

Author: Maryanne Demasi (maryannedemasi@hotmial.com), Institute for Scientific Freedom, Sydney, AUSTRALIA.

To cite: Demasi M. Outing drug company corruption comes at a cost. Indian J Med Ethics. 2021 Jul-Sep; 6(3) NS: 261-262. DOI: 10.20529/IJME. 2020.134.

Published online first on December 29, 2020.

Manuscript Editor: Sanjay A Pai

(C) Indian Journal of Medical Ethics 2020 the secrecy order and "conspired to steal" the documents. This much is already known to the reader from the back cover, but the book goes on to detail the cunning of Eli Lilly. With its team of lawyers and inexhaustible resources ( $p$ 79), it accuses Gottstein of conspiring to violate the Court's protection orders by creating a "sham subpoena" in order to access the documents. Gottstein is threatened with contempt of court charges, he faces the possibility of serving jail time and of having his law licence revoked. Readers witness the injustice of Gottstein effectively being punished for sounding the alarm on a sordid cover up that had cost lives. A judge rules that the publication of The Zyprexa Papers, which were "protected" documents, created "irreparable harm" to Eli Lilly (p 139), while simultaneously failing to address the potential for thousands of people damaged by the ruthless actions of the drug company.

Arguably, Gottstein loses the battle but wins the war. Exposing the documents not only saved lives, but served as an impetus for subsequent litigation against Eli Lilly where the company agreed to pay US $\$ 1.4$ billion to settle criminal and civil charges for its illegal off-label marketing of Zyprexa.

\section{The heroic patient behind it all}

The legal case of Bill Bigley serves as the basis for accessing the Zyprexa papers. Bigley is a heroic patient whose poor treatment in the psychiatric system becomes the backbone of the story. Bigley was administered antipsychotic drugs like Zyprexa against his will for over two decades, a practice known as "involuntary administration of psychotropic medication," or as Gottstein calls it, the cruel but legal practice of "forced drugging".

Gottstein takes on the case of Bill Bigley in order to subpoena the Zyprexa papers and expose what is described as the unethical and inhumane practice of forcing patients to take medication against their will. Bill Bigley developed tardive dyskinesia (a Parkinson's-like disease) from the large doses of antipsychotic drugs administered to him, and sustained permanent damage to his brain. Gottstein presents evidence that antipsychotics reduce people's lifespans and that for many patients, the drugs are ineffective and can cause brain damage.

In the book, Gottstein explains that he can relate to Bill Bigley because many years prior, he had encountered the 
same psychiatric system after suffering from a breakdown. Fortunately for Gottstein, he escaped the fate of becoming a permanent mental patient - Bigley wasn't so lucky. It's chilling when you realise that this sort of misfortune could happen to anyone.

Bill Bigley eventually succumbed to his drug-induced injuries and Gottstein has continued to advocate for patient's rights through his non-profit called "PsychRights", a public interest law firm that campaigns against forced psychiatric drugging and electroshock in the United States.

\section{My reflections}

As an investigative journalist, I have dipped my toe into these murky waters before. Exposing corruption at the big end of town rarely bodes well for whistle-blowers like Gottstein. No good deed goes unpunished and the messenger usually gets shot.

Reading this book transported me back to a time when I was a TV journalist for the Australian Broadcasting Corporation (ABC TV). I spent over a year researching and filming a documentary about victims of psychiatric drugs, the problems with industry-sponsored clinical trials and financially conflicted experts. Like The Zyprexa Papers, my story would divulge the tricks used by the drug industry to exaggerate the benefits of psychiatric drugs and underplay the harms. It would give a voice to the victims of "forced drugging" and expose the failure of drug regulators to protect its people. However, once the TV executives got wind of the programme, they moved swiftly to stop it from ever seeing the light of day, fearing retribution from Big Pharma and other vested interests. Rather than viewing it as a perilous act of censorship, TV executives preferred to file it under "risk-mitigation". The action taken against Gottstein was designed for the same purpose, of shutting down an inconvenient truth.

The ground-breaking work of physicians like Professor Peter Gøtzsche and journalists like Robert Whitaker have laid the foundation for people like Gottstein to continue to speak truth to power. Gottstein's story is not uplifting and the reader is left with the bitter aftertaste that, despite more than a decade on, patients are still forcibly drugged against their will and Zyprexa continues to be prescribed to millions of patients with little understanding of its harms. To add insult to injury, drug companies are now raking in the profits for developing new drugs to treat the harms caused by the old drugs. At a time when the suspicion of science and Big Pharma is already heightened, the events described in this book do nothing to allay those fears.

In my view, the most important aspect of the book - and why it is worth reading - is that it highlights the obligation of doctors to become fully informed about the harms of antipsychotic drugs and raises awareness of the circumstances in which a patient's right to consent to a medical therapy is violated.

\section{References}

1. Berenson A. Eli Lilly said to play down risk of top pill. New York Times. 2006 Dec 17[cited 2020 Dec 28]. Available from: https:// www.nytimes.com/2006/12/17/business/17drug.html 